Review

\title{
Setting Emission Reduction Trajectories in Mediterranean Cities with the Use of Science-Based Targets: The Pathway towards Climate Neutrality and the Ambitious European Goals by 2050
}

\author{
Eleni Feleki * (D) and Nicolas Moussiopoulos \\ Laboratory of Heat Transfer and Environmental Engineering, Aristotle University Thessaloniki, P.O. Box 483, \\ 54124 Thessaloniki, Greece; moussio@auth.gr \\ * Correspondence: efeleki@meng.auth.gr; Tel.: +30-2310994109
}

check for

updates

Citation: Feleki, E; Moussiopoulos, N. Setting Emission Reduction Trajectories in Mediterranean Cities with the Use of Science-Based Targets: The Pathway towards Climate Neutrality and the Ambitious European Goals by 2050. Atmosphere 2021, 12, 1505. https://doi.org/ 10.3390/atmos12111505

Academic Editor:

Rajasekhar Balasubramanian

Received: 21 October 2021

Accepted: 11 November 2021

Published: 15 November 2021

Publisher's Note: MDPI stays neutral with regard to jurisdictional claims in published maps and institutional affiliations.

Copyright: (c) 2021 by the authors. Licensee MDPI, Basel, Switzerland. This article is an open access article distributed under the terms and conditions of the Creative Commons Attribution (CC BY) license (https:// creativecommons.org/licenses/by/ $4.0 /)$.
Abstract: Mediterranean cities, having already suffered from climate change and at risk of being further affected if actions are not taken, need to reduce their emissions and set themselves on a path towards achieving the Paris Agreement ambition of limiting global warming to $1.5^{\circ} \mathrm{C}$. There are several methodologies that have been developed recently for cities in order to set a science-based target in line with a $1.5{ }^{\circ} \mathrm{C}$ scenario, that can be adopted by Mediterranean cities. In this short communication, we have selected to refer to two of them with the aim of inspiring experts from Mediterranean cities and providing relevant tools and further learning resources in order to make this task achievable. The new framework is guiding cities towards a greener and more sustainable transition. With a concrete framework to limit greenhouse gas emissions, the Mediterranean Basin can follow the global push to net-zero emissions by mid-century.

Keywords: climate change; climate neutrality; science-based targets; greenhouse gas emissions; Mediterranean; global warming; nature-based solutions; Fit for 55 package

\section{Greenhouse Gas Emissions and Climate Change in the Mediterranean}

The Mediterranean's more than half-a-billion inhabitants face "highly interconnected" climate risks. It is a region warming $20 \%$ faster than the global average, mainly due to anthropogenic emissions of greenhouse gases [1].

The annual mean temperatures across the Mediterranean Basin are $1.5^{\circ} \mathrm{C}$ higher in comparison to these recorded during pre-industrial times. Moreover, the annual mean temperatures are projected to rise until 2100 by an additional 3.8 to $6.5{ }^{\circ} \mathrm{C}$ in a high greenhouse gas concentration scenario. In a lower greenhouse gas concentration scenario, compatible with the long-term goal of the United Nations Framework Convention on Climate Change (UNFCCC) Paris Agreement, the temperature rise can be kept lower, ranging from 0.5 to $2.0^{\circ} \mathrm{C}$, to keep the global temperature well below $+2{ }^{\circ} \mathrm{C}$ above the pre-industrial level [2].

The level of warming strongly depends on the reference period definition, the future time horizon, and the level of greenhouse gas emissions [3]. Among the various greenhouse emissions produced by human activities, carbon dioxide $\left(\mathrm{CO}_{2}\right)$ contributes the greatest extent to climate change and is expected to continue rising if no action is taken [4]. Specifically, climate neutrality by 2050 means achieving net zero greenhouse gas emissions for European countries, mainly by reducing emissions through investing in innovative green technologies and enabling green transformation.

In an effort to hold greenhouse gas emissions to lower levels and to mitigate climate change and its negative effects, the newly introduced European Climate Law [5], adopted in June 2021, aims to regulate the goal that had previously been set out in the European Green Deal [6] for Europe's economy and society to become climate-neutral by 2050. The 
law sets the intermediate target of reducing net greenhouse gas emissions by at least $55 \%$ by 2030, compared to 1990 levels.

Despite a relatively low share in global greenhouse gas emissions $(6 \%)$, close to its proportion of the world population (7.4\%) [1], the Mediterranean region is severely affected by climate change. The impacts will be even more severe if no action is taken.

\section{Impacts of Climate Change in the Mediterranean}

Some of the most important impacts expected due to climate change in the Mediterranean Basin are listed below [1,7,8]:

- Seawater acidification;

- Sea level rise;

- Sea surface warming by 1 to $4{ }^{\circ} \mathrm{C}$ depending on the level of greenhouse emissions;

- Warming of deep waters in relation to other oceans in the world;

- Endangered food production;

- Increased demand for irrigation from $4 \%$ to $18 \%$ by 2100 ;

- Higher soil salinization;

- Increased land degradation;

- Reductions in crop yields;

- Biodiversity changes and loss of species;

- Homogenisation and simplification of biotic interactions;

- More frequent and intense extreme weather and climate events;

- Harder heatwaves: The Intergovernmental Panel on Climate Change (IPCC) draft predicts that up to 93 million more people in the northern Mediterranean could face high or very high heat stress by mid-century;

- Increased needs for energy to cool buildings and offices to cope with the extreme heatwaves, leading also to power instabilities;

- Drought and water shortage: summer rainfall will likely be reduced by 10 to $30 \%$ in some regions, increasing existing water shortages, desertification and decreasing agricultural productivity.

As an indirect result of the effects depicted above and as a direct effect as well, human health is impacted by high temperatures in the Mediterranean countries. Increased risks to human health, resulting from heatwaves, food and water shortages, vector-borne respiratory and cardio-vascular diseases, are the most severe ones. These health risks particularly impact disadvantaged or vulnerable populations, including the elderly, children, pregnant women and people on low incomes. Moreover, the risks from extreme events affect the safety of populations, particularly along coastal areas.

\section{Mitigation of Climate Change in the Mediterranean Countries}

The most comprehensive assessment of climate impacts ever assembled concludes that, "only a scenario in which global warming is limited to below $2{ }^{\circ} \mathrm{C}$ is likely to maintain coastal settlements, cultural heritage sites, land and ocean ecosystems in a viable state in most parts of the Mediterranean Basin" [1].

Mediterranean countries have a significant potential to mitigate climate change through an accelerated energy transition and interventions that include the reduction in fossil fuels and an increased share of renewable energy sources. The transition to energy efficient practices and more resilient techniques requires a significant transformation of energy policies and economic models in Mediterranean countries. While countries of the northern Mediterranean Basin make bigger steps towards this transition, some eastern and southern countries of the Mediterranean Basin are still in need of support, knowledge transfer, funding and competence building programmes. There is potential to increase the share of renewable energies to reach $13 \%$ to $27 \%$ under current transition scenarios until 2040 [8]. 
A more integrated response to climate changes calls for robust policies to mitigate the drivers of this change, mainly greenhouse gas emissions, and to proceed with interventions to smoothen the impacts. The role of cities is crucial in this direction.

\subsection{The Role of Cities}

An increasing number of cities are voluntarily taking part in transnational funding schemes, formulating networks active in climate mitigation and adaptation [9]. As these networks and initiatives have evolved, cities' ambitions and climate targets have increased to match or even go beyond the ambitions of countries [10].

Moreover, the regulatory framework is starting to be more demanding. The 2020s is the make-or-break decade for cities in order to meet the ambitious targets set by the European Climate Law. To safeguard the planet's future, cities must join all other actors in playing their part to reduce emissions and drive environmental action, in collaboration with all levels of government and all sectors.

The Mediterranean cities, home to 55\% of the European population [11], are on the frontline of climate change and have a vital role to play in meeting global targets [12]. With the population set to reach 657 million by 2050 in the Mediterranean [11], which is already extremely vulnerable to physical events, more people are likely to be affected in the future. In this context, Mediterranean cities need to take immediate actions to reduce their greenhouse gas emissions and mitigate climate change and its negative effects.

\subsection{Proposed Pathway: Science-Based Targets}

To what extent do cities need to eliminate their greenhouse gas emissions in order to be in line with the goals of the Paris Agreement and the Special Report on Global Warming of $1.5^{\circ} \mathrm{C}$ ? A scientifically justified answer lays upon the application of science-based targets. Cities setting science-based climate targets will benefit from clearly defined targets which specify the scale and pace at which they need to reduce their greenhouse emissions.

Science-based climate targets should be: (1) driven by climate science, (2) equitable and (3) reliable. Equitable means that they need to consider the varying historical levels of $\mathrm{CO}_{2}$ in the atmosphere and also reflect environmental and socio-economic progress. As with any kind of targets, these also need to be complete and comprehensive, taking into account city-wide emissions from different urban services and reflect at least Scopes 1 and 2.

\subsection{Methodologies for Projecting Greenhouse Gas Emissions: Setting Science-Based Targets}

There are several methodologies that have been developed recently for cities, in order to set a science-based target, in line with a $1.5^{\circ} \mathrm{C}$ scenario that can be adopted by Mediterranean cities. In this short communication, we have selected to refer to two of them with the aim of inspiring experts from Mediterranean cities and provide relevant tools and further learning resources in order to make this task achievable.

The Deadline 2020 (D2020) methodology was developed for cities in the C40 Cities network and outlines four different emission reduction trajectories depending on city's contexts of GDP and per capita emissions $[13,14]$. C40 Cities is a global network of mayors taking urgent action to confront the climate crisis and create a future where everyone can thrive.

The data required in order to apply the methodology are:

- Gross Domestic Product (GDP) per capita;

- Greenhouse gas emissions inventory/baseline year;

- $\quad$ Baseline year population and population growth until year 2050;

- City typology.

The steps in setting a science-based climate target using this methodology are listed below:

1. Gather city-wide greenhouse gas emissions for a selected baseline year. This can be achieved using the Global Protocol for Community-scale Greenhouse Gas Emissions inventories [14] or the Common Reporting Framework [15];

2. Gather population data for the same year, and population forecasts until 2050; 
3. Gather GDP data for the same year, and convert to USD;

4. Determine greenhouse gas emissions per capita and GDP per capita;

5. Select a city typology according to greenhouse gas emissions per capita and GDP per capita. To accomplish this step, one can refer to the D2020 Methodology report [16];

6. Apply reduction trajectory to the baseline year's per capita emissions until 2050;

7. Multiply D2020 per capita emissions from any year (until 2050) by the population forecast for the same year to obtain absolute emissions for that year.

Another methodology was developed by the World Wildlife Fund's (WWF) One Planet City Challenge (OPCC) [17]. The methodology builds upon the Deadline 2020 methodology, integrating new considerations of fair emissions budgets allocation compatible with the $1.5^{\circ} \mathrm{C}$ goal.

The methodology is suitable for any type of city that reports in line with the reporting requirements of Global Covenant of Mayors [18]. The methodology has been applied to 255 cities participating in OPCC Report for 2019-2020 [19].

The data that are required are the city-wide Human Development Index (HDI) score and the city-wide greenhouse gas emissions for a baseline year as close to 2018 as possible. The methodology can still be applied in the case of cities that lack a city-wide greenhouse gas emissions inventory, by using the city's Human Development Index (HDI) score. Cities that use this methodology need to report their environmental data on a yearly basis, including progress against targets. For this reason, they can use the platform MyCovenant [20].

Using the OPCC methodology to set a target includes the following steps:

1. Measure city-wide greenhouse gas emissions within Scope 1 and Scope 2 for 2018 and divide by population data (still 2018) to obtain baseline per capita emissions or obtain these data from the Global Protocol for Community-scale GHG Emissions Inventories (GPC) [14];

2. Find your country's Human Development Index (HDI) [21] to estimate a reduction target, from 2018 levels, that reflects a fair share of the $50 \%$ global emissions reduction by 2030 identified in the IPCC Special Report on Global Warming of $1.5^{\circ} \mathrm{C}$. Use the calculation formula:

Reduction target $=1-[0.5 \times($ HDI correction factor $)]$, where,

HDI correction factor $=1-(($ HDI Country where city is located-HDIGlobal average $) /$ HDIGlobal average);

3 Translate the 2030 target to a reduced per capita emissions value using the following calculation formula:

Baseline per capita emissions $\times(1-$ reduction target $)$;

4 Translate the 2030 reduced per capita emissions value to an absolute emissions value using the following calculation formula:

2030 reduced per capita emissions as calculated in step $3 \times$ forecasted 2030 population of the city.

This methodology works with the assumption that cities or countries grow at the same pace in terms of GDP. Information about GDP change rates at national level (and sometimes city level) is available from various trustworthy sources such as the United Nations Department of Economic and Social Affairs (UNDESA), the World Bank, OECD, European Commission open data platform, National Statistic Authorities, Cities' open data platforms, etc.

\subsection{Greenhouse Gas Emissions Inventories for Mediterranean Cities}

The scientific community notes the current lack of systemic knowledge of cities' quantified contribution to combating climate change [22]. This knowledge gap originates from many issues, including a lack of common methodological frameworks used for monitoring local emissions, a lack of reference scenarios and of common ambition targets, as well as the absence of a global, open and harmonised dataset of cities' emission inventories [23-25]. 
The first datasets published were published in 2019 in the academic literature; in the frame of the Global Covenant of Mayors (GCoM) initiative, a complete, verified dataset of greenhouse gas emissions inventories for 6200 cities in the Mediterranean Basin has been developed and is available [26-28]. The dataset is extremely valuable for communities engaged in climate action, including policymakers at all levels pursuing informed decisions, as demonstrated by the several and diverse studies based on the Global Covenant of Mayors for Climate \& Energy data that have appeared in the literature in recent years. Palermo et al. (2020b) discussed the mitigation policies at the local level [29]. Pablo-Romero et al. (2018) analysed the "benchmarks of excellence actions" [30]. Croci et al. (2016) analysed the major cities present at that time in the database [31]. Famoso et al. (2015) focused their study on the participation of signatories from Sicily [32]. Thanks to the dataset being available and the addition of a number of useful supplementary variables, more research studies are expected to evolve in the near future that will boost better informed decision making. Along with the dataset, the methodology to produce the data is available, as well as the corresponding metadata and the technical validation performed.

Moreover, in the frame of the monitoring of SDG 14 progress on climate action, more data that have a direct or indirect potential impact on cities' climate action plans have been collected using various other national and European valid resources, supporting further research on local climate action and monitoring [23,33].

Cities need to develop and maintain their own compliant and valid mechanism for monitoring their city-wide emissions and keep their inventories for monitoring actions and tracking progress.

\section{Interventions to Adapt to Climate Change in the Mediterranean: Nature-Based Solutions}

Mediterranean cities have common territorial and climatic specificities which are not shared with other macro-regions [25]. Mediterranean cities are especially vulnerable to the effects of climate change, while water shortages, droughts, forest fires or heatwaves are frequent in the region. Nature-based solutions $(\mathrm{NbS})$ provide a genuine opportunity for the Mediterranean. They have already made significant contributions toward climate resilience; to the conservation and promotion of urban biodiversity; and to the improvement of human well-being [34]. Examples of various interventions implemented in different Mediterranean cities are depicted below, aiming to inspire decision makers

1. Community Garden Janine For Homeless People, Aix-En-Provence, France The Garden Janine (formerly called Jardin Nouveau) group is participating in the "Aix en Transition" initiative, which wants to increase food and energy resilience in order to better prepare for the future. This group supports the establishment of a vegetable garden benefiting homeless people, hosted in the "Jas de Bouffan" district at the Humanitarian Pole. This is to improve the ordinary meals served to homeless people that are hosted by or visit the Halte de jour [35].

2. Intervention on a green roof, Alicante, Spain This underground garage in Alicante received a green roof makeover. The garden needs low maintenance and does not need any irrigation. The location of the garden in a relatively protected area, inside the inner courtyards and at the entrance of the building, have allowed an increase in the number of species and the variety of colours that would have been more limited in a more exposed area [35].

3. Urban Agriculture Office-City Strategic Agenda, Amman, Jordan In 2005, the Amman Municipality established the Urban Agriculture Office to encourage the farming of urban and peri-urban land, including rooftops and small plots between buildings. The Municipality has since launched several successful programs under the City Strategic Agenda to promote urban agriculture and to support inhabitants' engagement. In parallel, the Municipality has offered residents training, information, expertise, materials and access to credit. In the process, the Urban Agriculture Office has pursued a sustainable approach to farming by integrating recycling (e.g., collecting 
used tyres to convert them into flower pots) and other resource-efficient practices for water use, as part of the food security agenda. Instituted in one of the driest countries in the world, the City Strategic Agenda of Amman includes various initiatives to provide access to water, including the reuse of grey water, the introduction of drought-tolerant plants, rainwater harvesting and the creation of water reservoirs. The City Strategic Agenda also seeks to improve the life of the urban poor because home-grown food is cheaper, and the surplus may be sold, thereby generating additional sources of income for urban farmers. The city has encouraged the trading of home-grown products by creating a label guaranteeing product quality. The project now encompasses more than 300 rooftops and 4000 gardens in the city. In order to address Amman's pressing issues of water and food security, land fragmentation, and poverty alleviation, the city established an Urban Agriculture Office to underline the cross-sectoral and inter-departmental cooperation, between the Ministry of Agriculture and the Ministry of Environment [36], depicting the importance of integrated approach to deal with urban challenges.

4. Joining two parks with a green corridor, Athens, Greece The main idea of the project was to join the two parks at the end of the intervention (Pedion Areos and Lofos Likavitou), bringing back the greenery to an area that used to be a green zone in the outside of the old Athens walls. That green corridor is formed by: (1) the existing trees preserved; (2) the new trees added; (3) a continuous floor all along the project with a pattern that is an abstraction from olive tree branches; (4) the artificial activity/bioclimatic trees they create. The liberation of the space occupied until now by traffic has led to consideration of the uses and activities needed to be incorporated in the actuation to make it a liveable city [37].

5. Trees master plan, Barcelona, Spain The Trees Master Plan 2016-2035 has the overall aim of maintaining a well-managed, healthy and biodiverse woodland to add new green corridors and address the urban heat island effect. The quantity and quality of trees and their role as part of the city's greenery are factors that have been growing in importance in the city in the last few decades. Because of this, a strategy document was needed to guide municipal action in planning and managing all the trees in the city. One particular lesson for Barcelona was enabling enough space for planting street trees. Most street trees have very limited space in the ground for their roots, with very little organic material and a compact soil with deficient nutrition. In most instances, this is because pavements are narrow and tree pits are small, as this is a characteristic of most Mediterranean cities [24]. Therefore, in public areas, streets wider than six metres should be designed in a way that provides scope for transforming individual tree pits into continuous pits [35].

6. Bouregreg Valley Development Project, Morocco The Bouregreg Valley Development Project is one of 12 urban development projects selected during the project identification phase of the Urban Projects Finance Initiative (UPFI), launched by the Union for the Mediterranean. The project, which comprises the 3rd Phase of the Bouregreg Valley Development Plan, is the foundation of all urban development in this metropolitan area. It will develop new neighbourhoods for professional and residential use (to help improve social diversity), as well as public amenities and spaces. It will also preserve cultivated land, create natural ecological spaces, carry out reforestation activities and restore water courses that represent a risk of causing gully erosion and landslides. The project will foster an integrated development approach to meet the area's current and future needs, including benchmark facilities of benefit to the entire metropolitan area (including hospitals and the restoration of Chellah). Furthermore, it will deliver effective urban continuity between the two towns and improve road infrastructure, links, and traffic flow between the cities of Rabat and Salé. With a total budget of EUR 394 million, the project is being carried out in collaboration with public authorities and local stakeholders [38]. 
7. Urban agriculture in Cairo, Egypt The pilot case study titled, "Urban Agriculture in the Greater Cairo Region-The Example of Rooftop Farming in Informal Settlements", aimed to experiment with the use of rooftop farming as a means to reduce climate vulnerability in settlements. The implementation started with the selection of participants, followed by training and the technical setup. In order to be able to cover the costs for the technical installations, low-income families received repayable loans which were repaid by monthly crop sales. Farmers were typically able to repay the loans within one year. Families kept roughly $10 \%$ of the crops grown for personal consumption; the company that provided the loans purchased the remaining production, reselling it to local markets with profit for the farmers. A hydroponic system of waterbeds was proposed and installed directly on the rooftops. The model consisted of 3-4 water beds (of $3.75 \mathrm{~m}^{2}$ each) on each rooftop [39].

8. Multi-Site Urban Regeneration Project, Jericho, Palestine The Multi-Site Urban Regeneration Project in Jericho is expected to improve the climate conditions for 50,000 inhabitants of the city, and to also improve living conditions by reorganising and upgrading important public and leisure facilities and extending the city's green spaces. Moreover, the project will play a key role in improving the food security chain. The project also enables expansion of the municipal park into the current workshop area adjacent to the park and the construction of new leisure facilities (two swimming pools and a 3D cinema) [40].

\section{Future Challenges}

In July 2021, the European Commission announced the "Fit for 55" package [41], a set of policy proposals to achieve the $55 \%$ energy reduction target. These proposals will come into effect as soon as they are jointly approved by the European Parliament and Council. However they will set the pace for cities and industries in the European Union for the future steps. It is of great importance that Euro-Mediterranean cities are aware of these proposals and that they act not only towards their adoption, knowing and putting in practice already observed and tested, experimented good practices, but also towards the exchange of experience with the cities from the Southern rim, in order to join forces towards a better prepared future.

The proposals included in the Fit for 55 package are:

- Strengthening of the emissions reduction targets for each Member State;

- An increase in the target for renewable energy production to $40 \%$ by 2030 ;

- An update of energy efficiency targets for each Member State to $36-39 \%$ by 2030;

- A maximum limit on the GHG content of energy used by ships calling at European ports through the FuelEU Maritime Initiative;

- The introduction of an overall EU target for carbon removals by natural sinks, equivalent to 310 million tonnes of $\mathrm{CO}_{2}$ emissions by 2030;

- A new EU Forest Strategy, setting out a plan to plant three billion trees across Europe by 2030;

- A revision of the EU Emissions Trading System (ETS), and a new ETS for road transport and buildings;

- A Carbon Border Adjustment Mechanism, putting a carbon price on imports of iron and steel, cement, aluminium, fertilisers and electricity;

- A revision of the Energy Taxation Directive, introducing an EU-wide minimum tax rate for polluting aviation and shipping fuels;

- Higher $\mathrm{CO}_{2}$ emission standards for cars and vans, requiring average emissions of new cars to come down by 55\% from 2030 and 100\% from 2035 compared to 2021 levels;

- An obligation for fuel suppliers at EU airports to blend increasing levels of sustainable aviation fuels in jet fuel through the ReFuelEU Aviation Initiative. 


\section{Conclusions}

The new framework is guiding cities towards a greener and more sustainable transition. Mediterranean cities, having suffered already from climate change and at risk of being affected even more if actions are not taken, need to reduce their emissions and set a path towards achieving the Paris Agreement ambition of limiting global warming to $1.5^{\circ} \mathrm{C}$. With a concrete framework to limit greenhouse gas emissions, the Mediterranean Basin can follow the global push to net-zero emissions by mid-century.

Nevertheless, there is no doubt that disparities and variances exist between Mediterranean cities, mostly between the northern and the southern rim. It is vital that the EU's climate measures do not exacerbate social inequalities and that there is a fair share of the burden and an intense knowledge transfer and support. The Joint Research Centre (JRC), the science and knowledge service of the European Commission, as well as the Union for the Mediterranean, are able to provide scientific and technical support to Mediterranean cities in the development and implementation of their climate action plans.

Author Contributions: Conceptualization, investigation, writing—original draft preparation, submission and editing, E.F.; supervision, N.M. All authors have read and agreed to the published version of the manuscript.

Funding: This research received no external funding.

Institutional Review Board Statement: Not applicable.

Informed Consent Statement: Not applicable.

Conflicts of Interest: The authors declare no conflict of interest.

\section{References}

1. MedECC. Climate and Environmental Change in the Mediterranean Basin-Current Situation and Risks for the Future; First Mediterranean Assessment, Report; Cramer, W., Guiot, J., Marini, K., Eds.; Union for the Mediterranean, Plan Bleu, UNEP/MAP: Marseille, France, 2020; 632p, ISBN 978-2-9577416-0-1. [CrossRef]

2. The Paris Agreement UNFCCC. Available online: https://unfccc.int/process-and-meetings/the-paris-agreement/the-parisagreement (accessed on 18 September 2021).

3. Zittis, G.; Hadjinicolaou, P.; Klangidou, M.; Proestos, Y.; Lelieveld, J. A multi-model, multi-scenario, and multi-domain analysis of regional climate projections for the Mediterranean. Reg. Environ. Chang. 2019, 19, 2621-2635. [CrossRef]

4. Anderson, T.R.; Hawkins, E.; Jones, P.D. CO2, the greenhouse effect and global warming: From the pioneering work of Arrhenius and Calendar to today's Earth System Models. Endeavour 2016, 40, 178-187. [CrossRef]

5. Climate Law Regulation (EU) 2021/1119 of the European Parliament and of the Council of 30 June 2021 Establishing the Framework for Achieving Climate Neutrality and Amending Regulations (EC) No 401/2009 and (EU) 2018/1999 ('European Climate Law'). Available online: http:/ / data.europa.eu/eli/reg/2021/1119/oj (accessed on 20 September 2021).

6. European Green Deal. Available online: https://ec.europa.eu/info/strategy/priorities-2019-2024/european-green-deal_en (accessed on 20 September 2021).

7. 5th Intergovernmental Panel on Climate Change (IPCC) Report. Available online: https://www.google.com/url?sa=t\& $r c t=j \& q=\& e s r c=s \& s o u r c e=w e b \& c d=\& v e d=2 a h U K E w j V x d b X j Z r 0 A h X Z i v 0 H H f 2 W C Y s Q F n o E C B g Q A Q \& u r l=h t t p s \% 3 A \% 2 F \%$ 2Fwww.ipcc.ch\%2Fsite\%2Fassets\%2Fuploads\%2F2018\%2F05\%2FSYR_AR5_FINAL_full_wcover.pdf\&usg=AOvVaw2fktFYBr4 iuYXQCMiiMsek (accessed on 14 November 2021).

8. Koffi, B.; Cerutti, A.K.; Janssens-Maenhout, G. Projection to 2030 for setting emission reduction targets in the Southern Mediterranean Partner countries, An approach with a Business-as-Usual scenario. JRC 2017. [CrossRef]

9. Busch, H.; Bendlin, L.; Fenton, P. Urban Climate Shaping local response-The influence of transnational municipal climate networks on urban climate governance. Urban Climte 2018, 24, 221-230. [CrossRef]

10. Bertoldi, P.; Kona, A.; Rivas, S.; Dallemand, J.F. Towards a global comprehensive and transparent framework for cities and local governments enabling an effective contribution to the Paris climate agreement. Curr. Opin. Env. Sust. 2018, 30, 67-74. [CrossRef]

11. UN DESA. United Nations Department of Economic and Social Affairs. 2020. Available online: https://www.un.org/en/desa (accessed on 20 September 2021).

12. Edenhofer, O. Climate Change 2014: Mitigation of Climate Change; IPCC Working Group III Contribution to AR5; Cambridge University Press: New York, NY, USA, 2014.

13. D2020 Method Report. Available online: c40-production-images.s3.amazonaws.com/other_uploads/images/954_Deadline_2020 _Methodology_(1).original.pdf?1480603800 (accessed on 30 September 2021). 
14. Global Protocol for Community-scale GHG Emission Inventories. Available online: https://ghgprotocol.org/greenhouse-gasprotocol-accounting-reporting-standard-cities (accessed on 30 September 2021).

15. City Inventory Reporting and Information System (CIRIS). Available online: https://www.c40knowledgehub.org/s/article/ City-Inventory-Reporting-and-Information-System-CIRIS?language=en_US (accessed on 30 September 2021).

16. D2020 Methodology Report. Available online: https://www.c40.org/researches/deadline-2020 (accessed on 30 September 2021).

17. Explore the OPCC Assessment Framework 2019. Available online: https://www.france24.com/en/europe/20210806-un-reportsays-mediterranean-climate-change-hotspot-will-see-temps-20-higher-than-global-average (accessed on 30 September 2021).

18. Requirements for Global Covenant of Mayors. Available online: https://www.globalcovenantofmayors.org/faq/what-are-therequirements-for-committing-to-the-gcom/ (accessed on 30 September 2021).

19. OPCC Annual Report (2019-2020). Available online: https:/ / opcc.bc.ca/reports/annual-report/ (accessed on 30 September 2021).

20. MyCovenant Platform. Available online: https:/ / mycovenant.eumayors.eu/site/landing (accessed on 30 September 2021).

21. Global Human Development Indicators. Available online: http:/ / hdr.undp.org/en/countries (accessed on 30 September 2021).

22. Acuto, M.; Parnell, S.; Seto, K.C. Building a global urban science. Nat. Sustain. 2018, 1, 4-6. [CrossRef]

23. Kona, A.; Bertoldi, P.; Monforti-Ferrario, F.; Rivas, S.; Dallemand, J.F. Covenant of mayors signatories leading the way towards 1.5 degree global warming pathway. Sustain. Cities Soc. 2018, 41, 568-575. [CrossRef]

24. Feleki, E.; Vlachokostas, C.; Moussiopoulos, N. Characterisation of sustainability in urban areas: An analysis of assessment tools with emphasis on European cities. J. Sustain. Cities Soc. 2018, 43, 563-577. [CrossRef]

25. Feleki, E.; Achillas Ch Vlachokostas Ch Michailidou, A.V.; Ortega, L.; Moussiopoulos, N. Preservation of the Mediterranean Identity: An Intra-City Analysis Towards a Macro-Regional Approach for the Characterisation of Urban Sustainability. Sustainability 2018, 10, 3551. [CrossRef]

26. Adami, L.; Tubino, M.; Ragazzi, M.; Conti, F.; Rada, E.C. Local actions for reducing global greenhouse gas footprint: 10 years of Covenant of Mayors initiative. Int. J. Sustain. Dev. Plan. 2020, 15, 247-252. [CrossRef]

27. Kilkis, S. Data on cities that are benchmarked with the sustainable development of energy, water and environment systems index and related cross-sectoral scenario. Data Brief 2019, 24, 103856. [CrossRef] [PubMed]

28. Palermo, V.; Bertoldi, P.; Apostolou, M.; Kona, A.; Rivas, S. Data on mitigation policies at local level within the Covenant of Mayors' monitoring emission inventories. Data Brief 2020, 32, 106217. [CrossRef]

29. Palermo, V.; Bertoldi, P.; Apostolou, M.; Kona, A.; Rivas, S. Assessment of climate change mitigation policies in 315 cities in the Covenant of Mayors initiative. Sustain. Cities Soc. 2020, 60, 102258. [CrossRef]

30. Pablo-Romero, M.; del Pozo-Barajas, R.; Sánchez-Braza, A. Analyzing the effects of the benchmark local initiatives of Covenant of Mayors signatories. J. Clean. Prod. 2018, 176, 159-174. [CrossRef]

31. Croci, E.; Lucchitta, B.; Janssens-Maenhout, G.; Martelli, S.; Molteni, T. Urban $\mathrm{CO}_{2}$ mitigation strategies under the Covenant of Mayors: An assessment of 124 European cities. J. Clean. Prod. 2016, 169, 161-177. [CrossRef]

32. Famoso, F.; Lanzafame, R.; Monforte, P.; Scandura, P.F. Analysis of the covenant of mayors initiative in sicily. Enrgy. Proced. 2015, 81, 482-492. [CrossRef]

33. A dataset of GHG Emissions for 6200 Cities in Europe and the Southern Mediterranean Countries. Available online: https: / / doi.org/10.2905/57A615EB-CFBC-435A-A8C5-553BD40F76C9 (accessed on 17 October 2021).

34. IUCN. Nature Based Solutions in Mediterranean Cities. Rapid Assessment Report and Compilation of Urban Interventions (2017-2018); IUCN: Malaga, Spain, 2019; 117p.

35. Naturvation Project. Available online: https://www.naturvation.eu/ (accessed on 17 October 2021).

36. ICLEI. Available online: http://www.iclei.org/fileadmin/PUBLICATIONS/Case_Stories/Urban_NEXUS/26_Urban_NEXUS_ Case_Story_Amman_ICLEIGIZ_2014.pdf (accessed on 21 October 2021).

37. Re-Think Athens-Towards a New City Proposal. Available online: https://www.behance.net/gallery/7191429/Re-ThinkAthens-Towards-a-New-City-Centre-Proposal (accessed on 21 October 2021).

38. Union for the Mediterranean. Available online: http://ufmsecretariat.org/upfi-bouregreg-valley-developmentproject/ (accessed on 21 October 2021).

39. Urban Rooftop Farming Heat Wave Buffeing-Greater Cairo Region. Available online: https://panorama.solutions/en/solution/ urban-rooftop-farming-heat-wave-buffeing-greater-cairo-region-0 (accessed on 21 October 2021).

40. Union for the Mediterranean. Available online: http://ufmsecretariat.org/multi-site-urban-regenerationproject-in-jericho/ (accessed on 21 October 2021).

41. Fit for 55 Package. Available online: https://ec.europa.eu/commission/presscorner/detail/en/IP_21_3541 (accessed on 30 September 2021). 